Stellenbosch Theological Journal 2020, Vol 6, No 3, 301-351

DOI: http://dx.doi.org/10.17570/stj.2020.v6n3.a11

Online ISSN 2226-2385 | Print ISSN 0028-2006

2020 @ Pieter de Waal Neethling Trust

\title{
Raakpunte in die ontwikkeling van ekumene in die wêreld met ekumeniese ontwikkelinge in die gereformeerde kerke in Suid-Afrika (1990-2020)
}

\author{
Rudolph (RM) Van der Merwe \\ Universiteit van Pretoria \\ Pretoria, Suid-Afrika \\ rmvandermerwe@telkomsa.net
}

\begin{abstract}
Points of communality in the development of ecumenism worldwide with reformed churches in South Africa (1990-2020)
\end{abstract}

This historic-critical study analyses the development of ecumenism from 1990 to 2020 within the traditional Afrikaans speaking reformed churches in South Africa. The study attempts to determine whether the so-called change or shift in ecumenism within reformed churches and ecumenical bodies worldwide, influenced the theology and practice of ecumenism in Afrikaans-speaking churches in South Africa (1990 to 2020). Afrikaans-speaking reformed churches not only face political and social challenges in South Africa, but also face other major challenges brought about by a postmodern society and theological developments from 1990 to 2020. The development of ecumenism in reformed churches in the world, as described by Plaatjies-Van Huffel (2011:1-11) consists of a shift from conciliar ecumenism to transformative receptive ecumenism. In the past 30 years conciliar ecumenism took its stance in absolute certainties derived from a specific viewpoint on Scripture. Conciliar ecumenism partially failed because some reformed churches excluded other reformed churches from church unity, based on a particular interpretation of Scripture. These exclusions were claimed to be based upon the "authority" derived from Scripture. This ecumenical practice did not lead to significant church unity. The transformative receptive ecumenism, on the other hand, tends to reach out to the marginalised people of God, and not only try to transform the unrighteousness in the lives of people, but also tends to learn from and accommodate the needy in the understanding of ecumenism. If the developments in worldwide ecumenism influenced ecumenical thought among reformed Afrikaans-speaking churches, the question arises: to what extent was transformative receptive ecumenism able to contribute to a better understanding of ecumenism and church unity especially in the development of an African transformative receptive ecumenism. Also, if a shift in ecumenical practise took place, does that mean that the conciliar ecumenism of the past was of minimal importance? Is a new understanding of ecumenism (as 
in transformative receptive ecumenism) the alpha and omega of ecumenism in theory and practice? Shouldn't transformative receptive ecumenism be further discussed by all churches in South Africa and the world to bring forth an ecumenical model that suits the South African situation as part of worldwide ecumenism?

This chapter attempts to understand recent developments and issues within the reformed ecumenical societies and agencies in the world, after which the Afrikaansspeaking historic-reformed churches will be viewed in terms of the understanding of their calling to ecumenism. The developments and issues in the reformed world will be compared with the latest developments and issues within the Afrikaans-speaking reformed churches. A conclusion based on a comparison between ecumenism in the world and in South Africa will be drawn before some remarks on the future of ecumenical understanding concludes this study.

\section{Trefwoorde}

Ekumene; eenheid; ekumenisiteit; transformative receptive ecumenism; conciliar ecumenism; wêreld-ekumene

\section{Inleiding}

Om die ontwikkeling van ekumene in die histories gereformeerde kerke in Suid-Afrika (1990 tot 2020) histories-krities te analiseer, blyk dat nie net die ontwikkeling en tendense van hierdie kerke alleen ondersoek moet word nie, maar ook die ontwikkeling en tendense in die ekumeniese gesprek in die wêreld. Plaatjies-Van Huffel (2017:2-13) wys daarop dat gereformeerde ekumeniese besinning wêreldwyd in 'n al groter mate aandag bestee aan tendense in wêreldreligieë en tendense in kontemporêre ideologieë. Sy beskryf 'n wêreldwye neiging dat ekumene van die sogenaamde conciliar ecumenism na transformative receptive ecumenism geskuif het. Conciliar ecumenism was kerklike korrespondensie en eenheidsgesprekke wat meestal in gestruktureerde en formele riglyn-besluite gestol het. Transformative receptive ecumenism het ontwikkel waar ekumene gerig is om die onreg van die verlede reg te stel en om dit wat van gespreksgenote geleer kan word, te akkommodeer. Daarom behoort hierdie artikel ook rekening te hou met die sogenaamde "crisis, spirit of resignation" (Timmer 2014:362) of "phase of hibernation" (Kasper 2011:13) van wêreldwye, konfessioneelgebonde conciliar ecumenism die afgelope drie dekades. Hierdie studie let spesifiek op in watter mate hierdie sogenaamde verskuiwing in die ekumeniese gesprek ad rem was vir die histories gereformeerde kerke in 
Suid-Afrika in die konteks van groot politieke en sosiale veranderinge in Suid-Afrika sedert 1994 (vergelyk Olivier 2011:39-57).

Hierdie artikel poog om die volgende navorsingsvraag te beantwoord:

Het die sogenaamde verskuiwing in ekumeniese teologie en praktyk in die wêreld, te midde van die politieke en sosiale veranderinge in Suid-Afrika die afgelope drie dekades, 'n merkbare impak op die teologie en praktyk in ekumene in Suid-Afrika gehad, en, indien wel, in watter mate kan verandering in die grondslag van die ekumeniese diskoers van die afgelope dertig jaar waargeneem word.

Daar sal in die eerste plek kursories aandag bestee word aan die ontwikkeling van ekumene wêreldwyd, waarna tendense in die histories gereformeerde kerke (1990 tot 2020) kortliks aan die orde sal kom. Die bevinding van die huidige debat in Suid-Afrika sal in die konteks van wêreldwye ontwikkeling krities geanaliseer word om moontlike raakpunte te identifiseer, ten einde enkele strategiese penstrepe vir die toekoms te probeer trek.

\section{Tendense in die ekumeniese gesprek in die wêreld}

Ekumeniese handelinge in die wêreld het vir baie dekades rondom kerklike besluite van sinodes gesentreer. Die fokus was dat kerke die duurgekoopte eenheid wat Christus tussen hulle gesmee het, moet konkretiseer in een kerkverband (conciliar ecumenism). Maatstawwe en voorwaardes vir kerkeenheid moes op grond van 'n ooreengekome siening van die Skrifwaarheid sigbaar vestig. Ekumene moes die sonde-verskeurdheid van 'n gebroke en plurale ekumeniese gemeenskap weer herstel tot sigbare eenheid.

Die Protestante het redelik kort na die reformasie verdeel in Lutherse kerke, Gereformeerde kerke, Anglikaanse kerke en Pentekostalistiese kerke (McGrath 1995:412). Skismas het wêreldwyd voortgeduur, veral in kerke in die Nederlande. Gedurende die 19de en 20ste eeue was die verskynsel van skismas waarskynlik op sy ergste (Veenhof 1992:40-55). Dit blyk dat skismavorming aan die een kant ekumene negatief beïnvloed het, maar aan die ander kant ook positief gestimuleer het (vergelyk Van Wyk 2007:9;2007:4). Die behoefte aan ekumeniese gemeenskap het weer 
die opkoms van ekumeniese sinodes aangewakker, wat op sy beurt aan die doctrina en die goeie kerkregering help vorm het.

Sedert die ontstaan van die Wêreldraad van Kerke (WRK) in 1948 het ekumeniese organisasies en ekumeniese agentskappe die afgelope paar dekades 'n al groter invloed op kerke in hul ekumeniese praktyk uitgeoefen, in besonder die aandag wat ekumene aan wêreldreligieë en kontemporêre ideologieë in die wêreld gegee het.

In beide Gereformeerde en Katolieke studies en praktyk (vergelyk PlaatjiesVan Huffel 2017:1-13) was daar 'n beweging weg van die sogenaamde conciliar ecumenism (waar ekumene veral deur konsilies of sinodale handelinge van kerke bepaal is). Die WRK het na vore gekom met die transformative ecumenism (waar ekumene gerig is om die onreg van die verlede reg te stel) en die Rooms Katolieke kerk met die receptive ecumenism (waar ekumene daarop gerig is om dit wat van gespreksgenote geleer kan word, te akkommodeer).

Breuke en skeidings in Nederland het na die gereformeerde kerke in SuidAfrika oorgespoel (vergelyk Pont 1981:4-5; Kleynhans 1974:1-8; Spoelstra 1963:1-11). Hoewel daar tans geen kerkverband in Nederland is wat sonder spanning en meningsverskil bestaan nie (Douma 2008:11), het die kerklike ontwikkeling in Nederland die laaste tyd opmerklik verander. Die belangrikste veranderinge kan aan twee groot ekumeniese gesprekke tussen gereformeerde kerke toegeskryf word:

- Die Samen op Weg-beweging het in 2004 die ontstaan van die Protestantse Kerk in Nederland (PKN) tot gevolg gehad. Drie kerkgenootskappe het verenig om die PKN te vorm: die Nederlandse Hervormde Kerk (NHK), die Gereformeerde Kerken in Nederland (GKN) en die Evangelies-Lutherse Kerk (ELK).

- Die Federatiewe Groeiproses het intensiewe gesprekke en kontak tussen die Christelijke Gereformeerde Kerken (CGK), die Gereformeerde Kerk in Nederland (Vrijgemaakt) (GKN[v]) en die Nederlands Gereformeerde Kerken (NGK) gestimuleer.

Die aanvanklike sukses van die ekumeniese beweging laat in die 19de en vroeg in die 20ste eeu, het byvoorbeeld die ontstaan van die WRK gestimuleer. Die eerste WRK-vergadering het in Amsterdam (23 Augustus 
1948) vir 147 kerke met uiteenlopende dogmas en kerkregeringstelsels onderdak gebied. ' $n$ Spesiale Kommissie is in 1988 in Harare aangewys om ortodokse kerke se kommer oor lidmaatskap, besluitnemingstyl, openbare verklarings, wyse van aanbidding en ander sake te ondersoek. Behoudende kerke in die WRK wou hul posisie en rol in die WRK bepaal insake die WRK se uitsprake wat namens hulle gedoen word. Sommige kerke het op grond van hierdie rede besluit om nie langer deel van die WRK te wees nie.

Die Suid-Afrikaanse Raad van Kerke (SARK) is in Suid-Afrika deur die WRK in die lewe geroep. Tydens die apartheidsjare (1948-1994) was die verhouding tussen die SARK en die Afrikaanse Kerke in hoofsaak gespanne. Aansoek om waarnemerstatus van die GKSA (Acta GKSA 2006:176-177,190-191), is op 18 Julie 2007 goedgekeur, maar die aansoek is in 2009 (Acta GKSA 2009:233) teruggetrek. Die NG Kerk geniet sedert Junie 2016 saam met die Verenigende Gereformeerde Kerk in Suider Afrika (VGKSA) lidmaatskap, terwyl die Nederduitsch Hervormde Kerk van Afrika (NHKA) waarnemerstatus het. Die Afrikaanse Protestantse Kerk (APK) het nie aansoek om lidmaatskap gedoen nie.

Die Wêreldbond van Gereformeerde Kerke het met die Gereformeerde Ekumeniese Sinode (GES) in 2010 verenig om een ekumeniese liggaam te vorm: die Wêreldgemeenskap van Gereformeerde Kerke (WGGK). Die GES het in 1953 ontstaan op inisiatief van die Gereformeerde Kerke in Suid-Afrika (GKSA) en die CGK in Nederland. Die bedoeling van die destydse GES was om 'n gereformeerde sinode van kerke in die ware sin van die woord te wees - 'n tipe conciliar beweging waarvan die bedoeling was om as 'n ekumeniese sinode te funksioneer.

In Harare (1988) is die grondwet van die GES hersien en geringe aanpassings is goedgekeur. Verdeeldheid het tussen 1980 en 1994 geheers, in so 'n mate dat verskeie lidkerke, onder meer die GKSA uit die GES bedank het, omdat die GES, volgens die GKSA, afgewyk het van die gereformeerde konfessie. In die Rapport van die Algemene Sekretaris van die GES (Agenda 2005:6677) word veranderings aan die visie, missie en doel van die Raad bespreek. Die GES (Acts 2005:65-70) het, onder meer, 'n christelike getuienis te midde van religieuse pluralisme beredeneer: Christene behoort die waardigheid van alle mense met respek te erken en te versorg soos wat God sorg. Die sending van die kerk (missio ecclesiae) moet in ooreenstemming gebring 
word met God se sending (missio Dei) ... in 'n hartlike en oortuigende getuienis oor die “... hoop wat in julle leef ..." (1 Pet 3:15), met beskeie eerbied en eerbiedige beskeidenheid (1 Pet 3:16) soos vir God (vergelyk Bosch 1997:489).

Een van die eerste groot ekumeniese liggame was die Wêreldbond van Gereformeerde Kerke (WBGK) wat reeds in 1875 gestig is. Die NGK en die NHKA was lede van die Bond tot albei se lidmaatskap in 1982 gesuspendeer is as gevolg van die Bond se siening van apartheid. Die NGK se lidmaatskap is in 1998 ten volle herstel, maar die NHKA was vir 30 jaar in gesprek met die Bond voordat lidmaatskap van die WBGK verkry is. Die WBGK het in 2010 die WGGK geword (vergelyk Dreyer 2011:1-9). Die WGGK bestaan tans uit 233 lidkerke, saamgestel uit Kongregasioniste, Presbiteriane, Gereformeerdes, Verenigendes en Waldensiese kerke. Die WBGK moedig lidkerke aan om te hernu en die eenheid van kerke te soek. Kerke moet deel in God se transformasie van die wêreld. Van Suid-Afrikaanse kerke word vereis om eers deel te neem aan The World Alliance of Reformed Churches in South Africa (WARCSA), die SuidAfrikaanse vertakking van die WBGK, alvorens lidmaatskap oorweeg sal word. Die verkettering van apartheid as voorwaarde vir hertoetrede, wat die WARCSA aan beide die NG Kerk en die NHKA gestel het, dui op die verskuiwing wat in beide die ekumeniese liggaam en gereformeerde kerke in Suid-Afrika plaasgevind het.

The International Conference of Reformed Churches (ICRC) het op inisiatief van die Free Church of Scotland (FCS) en die GKN(v) in 1982 tot stand gekom. Die doel van die ICRC is: om die eenheid in die geloof, wat lidkerke in Christus het, uit te druk en te bevorder; om die volste kerklike gemeenskap in die uitvoering van die sendingroeping en ander opdragte te stimuleer; om algemene probleme en kwessies waarmee lidkerke te doen kry, te bestudeer en om oplossings vir hierdie sake te probeer vind en om 'n gereformeerde getuienis in die wêreld uit te dra (vergelyk ICRC Grondwet Art. 3). Die ICRC het in 2001 opdrag gegee dat die Interimkomitee 'n oorsig opstel om die reëls en verskillende terminologie vir ekumeniese gemeenskap in ooreenstemming te probeer bring - as riglyn vir ekumeniese gesprek (vergelyk Minutes ICRC 2001: Art. 42 en 73). Die ICRC (Minutes ICRC 2005 Art. 68) het gemeenskaplike Skriftuurlike perspektiewe vir ekumene 
geëien, maar gestuit daarvoor dat kerke hierdie beginsels op verskillende maniere in verskillende kulture toepas.

\section{Ekumene in die vier tradisionele Afrikaanse kerke in Suid- Afrika}

Hierdie afdeling poog om die ontwikkeling van ekumene in die Afrikaanse histories gereformeerde kerkgemeenskappe in Suid-Afrika uit te lig. Dit skyn dat die vier Afrikaanse kerke se ekumeniese posisionering naby aan mekaar is, aangesien al vier kerke dieselfde taal, belydenis en kultuur het, en elke kerk ekumeniese uitgangspunte begrond op die beginsels van die Sinode van Dordrecht (Van Staden 1995:1; Van der Linde 1965:128; Pont 1981:221-223; Kleynhans 1973:106; Vorster 1956:85). In praktyk blyk egter ook heelwat verskille (vergelyk Olivier 2011:1-20; Van Wyk 2007:4,9; Veenhof 1992:40-55).

\subsection{Die Afrikaanse Protestantse Kerk (APK)}

Artikel 64 reël ekumeniese betrekkinge van die APK met ander kerke. Die APK poog kontak met ander Christelike kerke op te neem. In ekumeniese kontak word onderskei tussen kerke van algemene Protestants-Christelike belydenis ("kontak") en kerke wat in belydenis die naaste aan die APK staan ("korrespondensie"). Die strewe om ekumeniese kontak het weinig eenheidsbelewing tot gevolg.

Wyer korrespondensie bestaan uit bilaterale gesprekke met ander Afrikaanse kerke en waarneming by die TKR en Konvent. Enger korrespondensie is moontlik met gereformeerde kerke met wie eenheid so nou beleef word in gesamentlike Nagmaalviering, oor-en-weer beroeping en aanvaarding van attestate (Kerkorde art. 62.2).

Buitelandse Christelike kerke wat in belydenis naby die APK staan (korrespondeer), kan met attestasie ontvang word nadat die vereistes van die Kerkorde met betrekking tot lidmaatskap nagekom is. (APK 1994:41; Kerkorde art. 64.2). Die reëling hou in dat voornemende lidmate onderskryf en onderteken dat slegs blanke persone lidmate van die APK kan word.

Die APK beredeneer dat kerklike eenheid (SKV 1998:31-43) alleen 'n geestelike eenheid is, en dat hierdie eenheid nie op enige wyse sigbaar 
hoef te word nie. Die APK gebruik deurentyd dieselfde begronding: "Daar bestaan 'n geloofseenheid, deur die Heilige Gees gesmee, tussen almal wat deel uitmaak van die algemene kerk, ondanks volks-, taal-, kultuur-, en tydsverskille. Dié eenheid word ook in elke plaaslike kerk in eie volksverband beleef" (SKV 1998:48).

Die stigting van die APK was te midde van radikale politieke veranderinge in Suid-Afrika. Dit is daarom nie vreemd nie dat geskrifte en besluite uit APK-geledere heelwat kontekstuele verantwoording oor eenheid en verskeidenheid reflekteer (vergelyk APK 1993:1-12; APK 1998:31-48; Van den Berg 1997:9-17; Maré 1997:21-35; Boshoff 1999:1-12). Die APK verstaan pluriformiteit as "die veelvormige gestaltes van die een kerk van Christus as gevolg van die verskeidenheidsgedagte, of selfs as resultaat van verskillende grade van suiwerheid" (SKV 1998:46; vergelyk ook Feenstra 1966:330-331). Die APK behoort gevolglik aan geen van bovermelde ekumeniese organisasies nie.

\subsection{Die Gereformeerde Kerke in Suid-Afrika (GKSA)}

Die begrippe korrespondensie (vergelyk Acta GKSA 1979:45), eenheid, bande en kontak (Acta 2000:206-210) word deur middel van konsentriese sirkels as ekumeniese verhoudinge omskryf. Die GKSA is daarvan oortuig dat ekumeniese gesprek, selfs binne 'n plurale en gedifferensieerde geloofsgemeenskap, uiteindelik in een kerkverband moet realiseer $(\mathrm{Du}$ Plooy 1984:42). Dit is ook die bedoeling van gesprekke oor taal- en kultuurgrense heen (vergelyk Grove 2004:9; Acta GKSA 2000:206-210; Du Plooy 1984:38). Dié beskouing het in die geskiedenis van die GKSA 'n spesifieke ontwikkeling gehad: Die sinode van die GKSA (Acta GKSA 1964:56) maak byvoorbeeld 'n onderskeid tussen kerke in verskeidenheid, wat in kerkverband moet konkretiseer, en kerke in geskeidenheid, waar samesprekings en of samewerking nodig is.

Die eenheid van gereformeerde kerke is sedert 1967 bestempel as die kerk se "dringendste en belangrikste ekumeniese roeping" (Acta GKSA 1967:365; Acta GKSA 1970:69). Daar sal noodwendig uiterlikeverskille tussen plaaslike kerke in verskillende wêrelddele voorkom (Acta GKSA 1997:171,2.1.1.4), byvoorbeeld verskille in die liturgie en bedieningsmetodes. Middelmatige verskille behoort nie in die weg te staan van ekumeniese eenwording nie. Skrifgebonde ekumenisiteit skep 'n raamwerk vir eenheid wat diversiteit 
behou en diversiteit wat na eenheid strewe (vergelyk Kerkorde art. 85; Acta GKSA 2009:343).

Die GKSA het besluit om nie by ekumeniese bewegings aan te sluit nie (Acta GKSA 1967:367,6), maar tog ingesien dat dit nodig mag wees om een of ander vorm van kontak te maak ter wille van die herstel van die verbroke eenheid van die kerk, waarskynlik samewerking in 'n losser ekumene soos byvoorbeeld die gemeenskaplike rade by die FCS (Acta GKSA 1997:170). Hierdie "losser" ekumeniese handeling impliseer "een of ander vorm van kontak" (Acta GKSA 1967:367; Acta GKSA 1970:89) kragtens Artikel 49 van die Kerkorde, sonder dat daarmee bedoel word dat noodwendig aangesluit moet word by ekumeniese liggame (vergelyk ook Acta GKSA 2009:344). Kerklike verhoudinge wat nie eenheid in leer, diens en tug (korrespondensie) vergestalt nie, word op meriete in elke indiwiduele geval gereël "soos dit nodig word" (Acta GKSA 1979:45). Die GKSA onderskei tussen die belewing van eenheid (kerke wat een in leer, diens en tug is), en die roeping tot ekumenisiteit wat missionêr uitgaan na alle kerke. Behalwe die roeping tot ekumenisiteit wat missionêr uitgaan, het kerke as ekumeniese gemeenskap ook 'n diakonale roeping om toe te sien dat geen kerk deur rampe, armoede of wat ook al, van die ekumeniese gemeenskap vervreemd raak nie. Afrika word steeds as 'n prioriteit geag vanweë die GKSA se besondere roeping en toekomsverbondenheid ten opsigte van sy tuiskontinent.

Die GKSA het op grond van 'n studieverslag (Acta 1961:43-119) die gelykheid van kerke oor kultuur- en kleurverskille heen aanvaar en in 1962 gesprekke met ander bevolkingsgroepe in die GKSA gevoer. Die gesprekke het gelei tot die selfstandigwording van die vroeëre "sendinggemeentes" wat in 'n algemene vergadering byeen sou kom. Hierdie algemene vergadering was aanvanklik bedoel om te konstitueer rondom 'n agenda, en nie rondom die samevoeging van bevolkingsgroepe nie. Die GKSA het reeds in 1966 eenheid oor volks- en taalgrense heen beleef toe die nasionale sinodes in die GKSA in 'n algemene sinode kon byeenkom. In Januarie 2009 is die eerste Algemene Sinode, wat op geografiese grondslag ingedeel is, afgehandel. Du Plooy (1986:48) het hierdie kerkregtelike reëling beskryf as "n plurale en gedifferensieerde geloofsgemeenskap in een kerkverband". 


\subsection{Die Nederduitsch Hervormde Kerk van Afrika (NHKA)}

Ordereël 6 van die NHKA se Kerkorde word begin met die woorde:

"Die kerk as verskyningsvorm van die een, heilige, algemene, Christelike kerk neem deel aan die ekumene in die wêreld." Vertrekpunte oor die eenheid van Christus se kerk hou die volgende in (NHKA Agenda, 2001:388-390): Ekumeniese eenheid is die eenheid wat in die Apostoliese Geloofsbelydenis bely word. Hierdie belydenis benadruk dat veelheid en verskeidenheid - wat altyd in die kerk waargeneem kan word - nie tot 'n kenmerk van die kerk verhef mag word in die sin dat die veelheid of verskeidenheid die eenheid ophef nie; die kerk is één aangesien dit in 'n verhouding met één Heer, Jesus Christus, staan. Net soos Christus één is, is sy gemeente ook één. Ten spyte van die veelheid van kerke, is die liggaam van Christus één.

Die WBGK het in 1982 in Ottawa verklaar dat die situasie van apartheid ten opsigte van die NHKA 'n status confessionis laat ontstaan het (vergelyk Norholt 1982:70). Dit het geïmpliseer dat die NHKA se beweerde teologiese regverdiging van apartheid die gemeenskaplike belydenis só in gedrang gebring het, dat geen verskille daaroor geduld kan word sonder om die integriteit van die gemeenskaplike belydenis wesenlik aan te tas nie. Die WBGK het gevolglik die lidmaatskap van die NHKA tydelik opgeskort, totdat daar algehele verandering in die besluite en handelinge van dié kerk sou kom. Die NHKA het onmiddellik na hierdie verklaring op 17 September 1982 uit die WBGK bedank.

Die standpunt van die NHKA met betrekking tot ekumeniese verhoudinge het in die laaste drie dekades aansienlik verander: Die Ekumeniese Raad van die NHKA het in 1998 aan die Algemene Kerkvergadering gerapporteer dat die kerk "op'n baie beperkte skaal deelneem aan ekumene in die wêreld" en dat die kerk "sukkel om hom los te woel uit ekumeniese isolasie wat hy tans beleef” (Acta NHKA 1998:315,316). Vorige besluite om ekumene te beoefen, het nie gewerk nie: Slegs bilaterale gesprekke met kerke, in plaas van ekumeniese liggame aan te knoop en om kerkpolitieke standpunte in te neem (vergelyk Acta NHKA 1998:316). Daarby was 'n apostoliese bewussyn en 'n ekumeniese sensitiwiteit van die NHKA gebrekkig.

Die NHKA het besluit om weer ekumeniese kontak met die WBGK te probeer hervat (Besluitebundel 2004:171) deur deel te neem aan die liggaam 
se aktiwiteite. Daar is ook besluit om kontak te soek met die SARK, die GES en lidkerke van die onderskeie rade. 'n Agtergrondstudie voor die Algemene Kerkvergadering (Agenda 2001:388-390; Besluitebundel 2001:186,187) het uitgeloop op ingrypende veranderings oor ekumeniese verhoudings. Veral drie kwessies op die Algemene Kerkvergadering in 2007 (vergelyk Besluitebundel NHKA:171-232) was vir ekumene belangrik: Die NHKA se ekumeniese verhouding met die WBGK; die verhouding (later genoem: gestruktureerde samewerking) met hul "dogterkerk": die Maranatha Reformed Christian Church (MRCC); asook die NHKA se verhouding met die ander Afrikaanse gereformeerde kerke in Suid-Afrika.

Hierdie pogings van die NHKA word deur Breytenbach (2011:1-8) 'n reis na "inklusiwiteit" genoem. Die NHKA het geslaag om na 30 jaar, in 2014 lidmaatskap van die WGGK te bekom (vergelyk NHKA 2018:190). Die NHKA het die vergadering van die WGGK op 26 Junie tot 07 Julie 2019 as lidkerk bygewoon (vergelyk Minutes WARC 2010:314).

Wat die MRCC betref, het die NHKA aanvanklik 'n ad hoc-benadering gehandhaaf: Insidentele geloofsgemeenskap - om mekaar op te skerp oor die waarheid wat hulle saam glo en bely (Acta NHKA 1982:305). Sedert 2000 is aanpassings in die benadering tot die MRCC gemaak: 'n meer konkrete belewing van eenheid in die vorm van gestruktureerde samewerking. Die nuwe benadering het ook geblyk uit 'n colloquium van predikante en lidmate wat op 29-30 April 2006 gehou is. Op hierdie byeenkoms is aangevoer dat ware ekumene vereis dat die NHKA los moet kom van die bagasie van Artikel III van die ou Kerkwet en die volkskerkgedagte in die nuwe Kerkorde (Ordereël 4). Oor die verhouding met die MRCC was die gedagte om aan kerkeenheid in 'n postmoderne sin te dink. Uit die bewoording van die besluit oor kerkeenheid, in besonder met die MRCC, en eventueel met die susterskerke (Besluiteregister NHKA 2007:171-173), blyk 'n bereidheid om opnuut te besin oor kerkeenheid en te soek na 'n moontlike model waarvolgens kerkeenheid met die MRCC kan konkretiseer.

Die NHKA handhaaf egter die standpunt dat ekumeniese gesprek nie noodwendig tot strukturele eenheid hoef te lei nie en dat insidentele kontak reeds die belewing van eenheid inhou (Acta TKK 1989:663; Besluitebundel NHKA 1994:249;2004:144). Die verskeidenheid van gereformeerde kerke 
met dieselfde taal en belydenis in een land dui dus nie vir alle kerke op 'n sondige verskeurdheid van die liggaam van Christus nie, soos dit byvoorbeeld in die pluriformiteitsleer van Kuyper na vore kom (Van Wyk (jnr.) 2003:4;2004:4). "Organisatoriese eenheid van die kerk is nie 'n dwingende Skriftuurlike eis nie” (Acta TKK, 1982:309). Die eenheid van die kerk van Christus lê nie noodwendig in die sigbare en organisatoriese eenheid tussen volkskerke nie (Acta TKK 1977: 212-217).

Ten opsigte van die lank gevoerde gesprek (sedert 1956) oor kerkeenheid binne die TKR, spreek die algemene kerkvergadering sy dank uit dat die saak van kerkeenheid sodanig gevorder het "dat die Kerke saamstem dat daar 'n duldbare verskeidenheid kan bestaan. Dit beteken dat kerke naas mekaar kan bestaan sonder dat dit noodwendig'n aanduiding van 'n sondige verskeurdheid hoef te wees. As sodanig kan verskillende kerkformasies deel wees van die een heilige algemene Christelike kerk" (Besluitebundel NHKA 1998:321). Volgens die NHKA word hierdie eenheid in waarheid en belydenis vergestalt wanneer die NHKA en kerke wat op dieselfde belydenisgrondslag staan: mekaar se lidmaatskap aanvaar; kanselruiling in beginsel aanvaar; predikante in beginsel kan beroep en lidmate uitnooi om saam aan die Nagmaalstafel aan te sit.

Via 'n belangrike dokument, Kerk en wêreld 2000 (NHKA 1985), het die definiëring van volkskerk, soos dit in Ordereël 4 van die Kerkorde verwoord is, aandag gekry: "Die kerk is 'n volkskerk met sy eie kerklike kultuur, geskiedenis, taal en tradisie wat geroepe is tot die verkondiging van die evangelie van Jesus Christus aan die Afrikanervolk en tegelykertyd aan alle mense."

Oberholzer (1999:456-458) en Dreyer (2007:5) wys teenstrydigheid in Ordereël 4 van die Kerkorde uit: Om die kerk in een asem die gemeenskap van gelowiges te noem en daarna te koppel aan 'n volk as volkskerk, rym nie. Die kerk kan nie apostolêr gerig wees op alle volke en tegelyk 'n kerk vir Afrikaners wees nie. Die Kommissie van die Algemene Kerkvergadering het algaande 'n meer kritiese houding jeens die volkskerkgedagte begin inneem via 'n strategiese beplanning wat 'n missionêre visie vir die NHKA geformuleer het (Kommissie AKV 2005:2). In 'n stemming gedurende die Algemene Kerkvergadering in 2007 stem 51\% vir die verwydering van die volkskerkgedagte uit die Ordereëls. Die vereiste tweederdemeerderheid kon 
egter nie behaal word om die Kerkorde te wysig nie (vergelyk Besluitebundel NHKA 2007:200). Die verwysing na die NHKA as 'n volkskerk het in die NHKA 'n veelbesproke saak geword (vergelyk Dreyer 2007:5; Dreyer 2007:6; Pretorius 2007:6; Kriel 2007:2; Steenkamp 2007:6; Van Wyk 2007:6).

Die NHKA het in 2013 die onbehaaglike situasie moes hanteer dat 'n aantal meer behoudende kerke (Geloofsbond van Hervormde Gemeentes) weggeskeur het van die NHKA.

\subsection{Die NG Kerk-familie}

Behalwe Kerkorde Artikel 70, identifiseer die NGK die volgende kernagtige uitgangspunte in verband met ekumeniese betrekkinge (vergelyk Handelinge NGK 1990:546-548): “Die een kerk is 'n gawe en 'n roeping vir die kerk. Verskeidenheid moet erken word, maar nie tot geskeidenheid lei nie. Die NG Kerk wil aktief deur die Algemene Sinode ekumeniese gemeenskap met ander christelike kerke en ekumeniese organisasies stimuleer, handhaaf en bevorder. Die NG Kerk se ekumeniese beleid (Handelinge NGK 2007:31-37; Handelinge NGK 2002:384-387) word op bilaterale en multilaterale wyse in ekumeniese betrekkinge vergestalt."

Die proses van eenwording binne die NG Kerk-familie het'n eie geskiedenis deurloop, maar momente daarvan vertel in die kleine die verhaal van vele ekumeniese prosesse en gesprekke wêreldwyd. Die NGK in die Kaap het in 1857 besluit om gekleurdes wat tot bekering kom, in 'n afsonderlike gebou byeen te bring weens "de zwakheid van sommigen" in die "blanke" gemeentes (Acta NGK 1857:58,60,89,XII(5); Kleynhans 1977:305,306). Die Algemene Sinode van die NGK het hierdie oorspronklike motivering vir afsonderlike kerke in 1974 aangepas om só te lui: "Die bestaan van afsonderlike Ned. Geref. Kerkverbande vir verskillende bevolkingsgroepe word erken as in ooreenstemming met die Skriftuurlik meervormige bestaanswyse van die kerk ..." (Ras, volk en nasie, 1975:83; vergelyk bespreking van pluriformiteit hierbo).

$\mathrm{Na}$ jarelange intensiewe gesprek klink die verbintenis van die Algemene Sinode van 2000 in 'n opdrag aan die Algemene Sinodale Kommissie (Handelinge NGK 2000:422) oënskynlik kontrasterend met vorige besluite oor eenheid in die NG Kerk-familie: "Die Algemene Sinode verbind hom opnuut daartoe om, onder die beskutting van die Here, in samewerking 
met ander lede van die NG Kerk-familie, een kerkverband tot stand te bring" (vergelyk Acta Algemene Sinode NGK 2004: 383-385).

Sedert 2000 is goeie vordering in bilaterale en multilaterale gesprekke tussen die NGK, Reformed Church in Africa (RCA); die VGKSA en die Nederduitse Gereformeerde Kerk in Afrika (NGKA) gemaak. Bilaterale gesprekke met die VGKSA, soos met die NGKA en die NGK, het verskeie uitdagings gebied (Acta Algemene Sinode NGK 2004: 383-385; Acta Algemene Sinode NGK 2007: 23vv; Acta Algemene Sinode VGKSA, 2008:194vv). Een van die grootste deurbrake in die eenheidsgesprek tussen die NGK en die VGKSA, wat Durand (2008:9) as "n wonderwerk" bestempel, het te Esselenpark plaasgevind. Die NGK en die VGKSA kon 'n ooreenkoms bereik (vergelyk Verbondsverbintenis tot hereniging van die familie van NG kerke. Esselenpark Verklaring 21 en 22 Junie 2006) ten opsigte van die rol van die Belhar Belydenis as belydenis van 'n verenigende kerk. Albei kerke het toegestem dat dié belydenis nie as voorwaarde vir eenheid sal geld nie, hoewel dit 'n belydenisskrif van die nuwe kerk kan wees en daar saamgewerk sal word om die kerk te help groei tot 'n volledige aanvaarding daarvan.

Verhoudinge tussen die NGK en VGKSA het sedert Junie 2008 begin verswak. Die VGKSA (Algemene Sinode, Hammanskraal 2008:196-197) het besluit om 'n moratorium op die eenheidsgesprek te plaas. Die rede vir die radikale besluit kom daarop neer dat die NGK volgens die VGKSA nie by die ooreenkoms by Esselenpark en Achterberg gehou het nie met sy besluit van 2007: “... 'n verenigende kerkverband van selfstandige plaaslike gemeentes". Hierdie besluit heropen volgens die VGKSA die verwerping van die Belhar-belydenis as deel van die konfessionele basis van die nuwe kerk waarop die VGK gehoop het. Die NG Kerk (vergelyk Strauss 2010:135142) het die ooreenkomste egter anders geïnterpreteer.

Die proses van bemiddeling deur die WBGK het met 'n byeenkoms in Maart 2009 begin. Die fasilitering van die proses sou al vier die lidkerke van die NG Kerk-familie in hierdie bemiddeling betrek. Ondertussen het die VGKSA onderlinge worstelinge gehad, onder meer met die NGKA wat aanvanklik op 'n hofsaak - en toe weer op 'n ooreenkoms uitgeloop het (Nederduitse Gereformeerde Kerk (OVS), Nederduitse Gereformeerde Kerk 
in Afrika; Phororo en die Verenigende Gereformeerde Kerk in Suider-Afrika Saaknommer 536/96).

Die NGK het sedert 2010 aansoek gedoen om lidmaatskap van die SARK en die WRK, waar die VGKSA die aansoeke ondersteun het as versoeningsgebaar (vergelyk Brief namens die Uitvoerende Komitee VGKSA - Plaatjies-Van Huffel 2016). Die gesprekke tussen die VGKSA en die NGK onder die leiding van die WARC het meegehelp dat die NG Kerk besluit het op 'n kerkordelike weg te vind waarop die Belhar-belydenis deel van die konfessionele basis van die NG Kerk sal uitmaak (vergelyk Acta Algemene Sinode NGK 2011: 128vv.). Die VGKSA (Acta Algemene Sinode 2012:11-12) het besluit om die moratorium van 2008 op te skort in die lig van die NG Kerk se besluite van 2011. Albei moderature het in 2012 tot 'n memorandum van ooreenkoms ingestem. Die hele NG Kerk-familie het besluit om 'n seisoen van menswaardigheid aan te pak, wat inhou: respek, luister, omarming en liefde (vergelyk Acta Algemene Sinode NGK 2013:251vv).

In 2015 kon die NG Kerk egter nie die verwagte tweederde-meerderheid verkry wat nodig was om die NGK se belydenisgrondslagte te verander om plek te maak vir die Belhar Belydenis nie. Tog kon die NG Kerk-familie regkry om 'n tussen-orde as kerkregtelike weg op te stel en goedgekeur te kry by die VGKSA en die NGK sinodes.

\subsection{Die Tussenkerklike Raad (TKR) en die Konvent van Reformatoriese Kerkgemeenskappe in Suider-Afrika (Konvent)}

Die besondere verhouding tussen die Afrikaanse histories-gereformeerde kerke, wat vanaf 1958 in die Tussenkerklike Kommissie (TKK) tot uitdrukking gekom het, het in Februarie 2004 uitgeloop op die stigting van die Tussenkerklike Raad (TKR). Hierdie verhouding het gegroei uit 'n gemeenskaplike reformatoriese herkoms, 'n gesamentlike sosio-historiese konteks en 'n gemeenskaplike taal.

Gedurende 1994 lei 'n evaluering van die stand van die gesprek tussen die drie Afrikaanse kerke tot die volgende besluit (1994-09-22 - par. 4.3.4.4.7) wat uiteindelik die grondlyn vorm vir die daarstel van die Konvent van Reformatoriese Kerkgemeenskappe in Suider-Afrika: "Die TKK neem die inisiatief om uiteindelik een liggaam wat verantwoordelik is vir die 
bevordering van eenheid tot stand te bring." Die Konvent poog om, deur middel van ad hoc-byeenkomste, vir reformatoriese kerkgemeenskappe die geleentheid te skep vir getuienis op grond van die reformatoriese belydenisskrifte, en om te besin oor gemeenskaplike sake wat van tyd tot tyd in die Suid-Afrikaanse samelewing mag voorkom.

In 1997 vind 'n indringende gesprek oor die “TKK op pad na 2000" te Nooitgedacht plaas. In opvolging van hierdie gesprek word die volgende doel vir die TKK gestel (Notule Interim, 25/04/97, 3.1): “Op grond van die gemeenskaplike belydenis van die NGK, NHKA en GKSA stel die TKK hom ten doel om in 'n gees van onderlinge liefde die Bybelse roeping tot eenheid en kerkwees in die wêreld na te strewe." Hiermee verskuif die fokus in die gesprek van dinge wat die kerke uitmekaar hou na dinge wat die kerke gemeenskaplik het (Notule Interim 22/11/99:5.1). Hierdie gesprek lei uiteindelik daartoe dat die TKR gevorm word waarin die bestaande terreine van samewerking kerkregtelik gefundeerd gekoördineer kan word (Notule TKK 19/03/01:7.1.4).

Sedert 1989 word binne die TKK en TKR gewerk met die vertrekpunt dat organisatoriese eenheid op daardie stadium nie haalbaar is nie - 'n vertrekpunt wat enersyds lei tot groter klem op die uitbou van samewerking, maar andersyds in die praktyk die hele gedagte van kerkvereniging op die lange baan geskuif het. Met verloop van tyd is daar tog gevorder op die pad van eenheid - soos blyk uit die vorming van die Konvent en later ook die TKR, asook die vraag oor 'n moontlike verklaring van voorneme en die moontlikheid van 'n "samen op weg"-proses (vergelyk Notule TKR 2006:223). Na aanleiding van die gesprek is die Interim-komitee versoek om 'n dokument saam te stel wat die stand van die huidige debat oor kerkeenheid in die TKR sal reflekteer (vergelyk Notule TKR 2006:12). Die dokument oor die debat wat op daardie stadium gevoer is, is bespreek en uitgebrei met 'n tabulering van vorige gesprekke van die TKK (en TKR) oor leerstellige en kerkregtelike sake (ooreenkomste en verskille). Die dokument was bedoel om stimulus te gee aan die gesprek oor kerkeenheid in die TKR (Notule TKR, 2007:7). Die uiteinde van die besinning het uitgeloop op 'n konsensusbesluit: dat strukturele eenwording tussen die drie kerkgemeenskappe op daardie stadium nie moontlik was nie. 
Bilaterale gesprekke tussen die NGK en die NHKA het ondertussen sodanig ontwikkel dat die twee kerkgemeenskappe memoranda van volle samewerking op hul onderskeie sinodes aanvaar het (Acta AKV NHKA 2010: 237). Dit sluit allerlei vorme van samewerking in, onder meer kanselruil, aanvaarding van attestate wedersyds en gedeelde opleiding. Bilaterale gesprekke tussen die NGK en die GKSA het, na aanvanklike teenslae, uitgeloop op 'n memorandum van samewerking wat op beide kerkgenootskappe se sinodes goedgekeur is.

Die TKR staan in die voorportaal om met hierdie nuwe uitdagings te handel. Dit blyk dat veral die NGK en die NHKA die doel van die TKR wyer wil vertolk as die blote instandhouding van die tradisionele betrekkinge van die drie kerke onderling. Die GKSA en die NGK het ondertussen struktureel verander in die opsig dat die NG Kerk haar "dogterkerke" insluit, en dat die GKSA weggedoen het met afsonderlike Nasionale Sinodes vir die onderskeie bevolkingsgroepe. Die NHKA vorder ook in hul gesprek met die MRCC op die weg van groter samewerking.

\section{Raakpunte tussen ekumene in die wêreld en in histories gereformeerde kerke in Suid-Afrika (1990-2020)}

Die navorsingsvraag in die inleiding sentreer rondom die kwessie: In watter mate het verskuiwings in die ekumene wêreldwyd 'n impak gehad op die ekumene die afgelope drie dekades van die histories-gereformeerde kerke in die konteks van 'n veranderde Suid-Afrika?

Dit blyk uit die analise van ekumene in die wêreld dat met Plaatjies-Van Huffel (2014:1-13) en ander saamgestem kan word dat daar stelselmatig wegbeweeg is van 'n sogenaamde conciliar ecumenism na ' $n$ transformative receptive ecumenism. Dieselfde waarneming kan in 'n mindere of meerdere mate van die Afrikaanssprekende gereformeerde kerke in Suid-Afrika gemaak word.

Byvoorbeeld, in die missie-stelling, fokus en doelstellings van ekumeniese bewegings (soos die WBGK; in 'n minder mate ook die ICRC [en selfs die TKR]) blyk 'n duidelike verskuiwing weg van 'n sigbare eenheidsoeke, gegrond op 'n bepaalde beskouing van eenheid in waarheid. In die onhaalbaarheid van eenheid in kerkverband (TKR 2001:8) en die soeke na samewerking en gesamentlike getuienis in evangelisering (sien pt. 
3.5 hierbo), blyk dat tradisionele Afrikaanssprekende kerke stelselmatig wegbeweeg het van 'n sigbare eenwordingsideaal van veral die GKSA en die NGK.

Ekumene in die gereformeerde wêreld het bepaalde uitdagings die hoof moes bied, soos die vernietigende skismas wat ontstaan het as gevolg van conciliar ecumenism. Skismas in gereformeerde kerke het nie die werklike probleme van 'n wêreldkonteks met sy demokratisering en globalisering aangespreek nie. Die skade wat voortdurende skismas aan die konteks van ekumene in Suid-Afrika berokken het, word gevoel in vier tot vyf Afrikaanse gereformeerde kerke wat blyk al hoe verder van mekaar af te beweeg (vergelyk pt 3.5 hierbo). Die skade wat skeuring in Afrikaanse kerke berokken het, wreek hom ook in die versplinterde 'dogterkerke' in Suid-Afrika.

Ook die soms teenstrydige, eksklusiewe maatstawwe en terminologieë wat kerke en ekumeniese liggame aangelê het as voorwaardes vir ekumeniese eenheid, was kerklike ekumene nie tot eer nie (vergelyk Van der Merwe 2009:18). Gelowiges wat in fisiese nood in die wêreld verkeer, het die behoefte blootgelê vir meer omvormende ekumenisiteit (transformative ecumenism) en die paternalistiese houding jeens mense wat gemarginaliseer is in die wêreld, moes plek maak vir ekumenisiteit, wat meer wil akkommodeer en leer (receptive ecumenism) van mense in nood. Afrikaanse gereformeerde kerke (in 'n minder mate die NGK) is bekend daarvoor dat hul absolute maatstawwe en vereistes vir eenwording voorgestaan het. Die vraag oor uitsluitende maatstawwe kan moontlik gevra word ten opsigte van die aanvaarding van Belhar as voorwaarde vir kerkeenheid al dan nie (vergelyk pt. 3.4.1 hierbo).

Kerkvergaderings van Afrikaanssprekende gereformeerde kerke wy dekades al aandag aan die missionale karakter van die kerk. Die missionale roeping van die Afrikaanse gereformeerde kerke rig kerke op die pluraliteit van die Suid-Afrikaanse kerkgemeenskap. Die ongelykhede van die verlede in Suid-Afrika laat gereformeerde kerke in ekumene met missionale deernis op die gevolge van so 'n gebroke en plurale ekumeniese gemeenskap fokus.

Die debat rondom die heersende hermeneutiek van gereformeerde kerke wat in die wêreld in swang is, het sekerlik ook invloed in Suid-Afrika uitgeoefen, byvoorbeeld oor die interpretasie van die Skrif en die reg op 
die waarheid van die Skrif. Die bevraagtekening van skrifhantering en die siening van skrifgesag het heelwat "sekerhede" oor ekumenisiteit laat sneuwel. Die Afrikaanse kerke worstel elkeen met die hermeneutiek in die verstaan van die Skrif.

Die skuif weg van conciliar kan krities-analities ongemak veroorsaak met die vraag of alles in die conciliar ecumenism niksseggend was en of die transformative receptive ecumenism die utopie vir ekumeniese teologie en praktyk gebring het. Wanneer so 'n radikale skuif plaasvind, moet vasgestel word in watter mate die skuif begrond is op 'n verantwoorde bibliologiese en ekklesiologiese basis. Uit die navorsing blyk dat die skuif in die ekumeniese wêreld aansluiting vind by die uitgangspunte van wêreldreligieë en kontemporêre ideologieë, byvoorbeeld transformerendbevrydende en inklusiewe ekumene; en die gesindheid agter ekumeniese bewustheid en die Hoof- en Koningskap van Christus. Die fokus van ekumene het inderdaad verskuif van 'n ekklesiologiese en konfessionele binding, na 'n vryer en oper tipe van ekumene te midde van religieuse pluralisme.

Die skuif in ekumeniese gerigtheid het waarskynlik ook te doen met 'n bepaalde verstaan van die begrip: eenheid/verskeidenheid. Agter die verstaan van die begrip is daar waarskynlik 'n bepaalde kerkbegrip. Kerkbegrip is weer inherent deel van die ekklesiologie, wat op sy beurt weer die gevolg is van 'n skrifbeskouing wat skrifgesag en skrifhantering bepaal. Hoe dringend die roeping van kerke in ekumene by 'n gebroke en plurale wêreld is, bly 'n skrifgefundeerde verstaan van eenheid en verskeidenheid wesenlik in alle ekumene.

\section{Strategiese pennestrepe vir die ekumeniese gesprek vorentoe}

Gereformeerde kerke in Suid-Afrika het oor die laaste dertig jaar in 'n mindere of meerdere mate daarin geslaag om die unieke nood van God se kinders in Suid-Afrika in 'n meer inklusiewe, transformerende en akkommoderende of lerende ekumene rak te sien. Die rol wat ekumeniese bewegings (soos die WGGK, die GES en die TKK) by sommige gereformeerde kerke gespeel het, moet vermeld word. 
Die wegbeweeg van die conciliar ecumenism na 'n transformative receptive ecumenism hoef nie noodwendig 'n (beperkende) bloudruk te wees van wat in ekumene in Suid-Afrika gebeur nie. Daar kan baie by wêreldekumene geleer word, maar die veelkleurige verskeidenheid wat wesenlik aan SuidAfrika is, moet ook in die Suid-Afrika en Afrika model weerspieël word. Die positiewe wat uit 'n meer transformative receptive ecumenism gehaal kan word, behoort verder uitgebou word om spesifiek antwoorde te bied ten opsigte van die ekumeniese uitdagings van 'n vinnig groeiende, tipies (Suid-) Afrika, tafereel van kerke ... steeds gefundeer op die Skrif!

Die moeisame pad wat histories gereformeerde kerke in Suid-Afrika reeds deurloop het (nasionaal en internasionaal), skep 'n basis waarop inklusiewe, saam-ontdekkende denke verder kan voortbou. Die Here het aan Suid-Afrikaanse teoloë 'n besondere gawepoel gegee om verantwoorde teologiese begronding te bied vir 'n tipies (Suid-) Afrika ekumene. Deel van verantwoorde teologiese begronding kan juis wees om nie bloot na die teenoorgestelde van ekumene in die verlede oor te slaan nie, maar om ook die goeie uit die conciliar ecumenism te erken en 'n tipies (Suid-) Afrika manier van ekumene te bou op iets soortgelyks aan die benadering van die transformative receptive ecumenism.

Op een of ander manier sal ekumene op die grondvlak moet uitkom sodat gereformeerde ekumene 'n lewensstyl van elke gereformeerde lidmaat sal wees. Een van die uitdagings van gereformeerde kerke sal wees om ekumeniese programme van grondvlak boontoe te laat werk en nie soseer van sinodevlak af ondertoe (conciliar ecumenism) nie. Die getuienis van 'n lifestyle-gebaseerde, inklusiewe, transformerende en ontvangende ekumeniese reis kan in die toekoms baie beteken vir ekumene in die algemeen, en ook vir die land as geheel. Eenheid in Christus in die veelkleurige verskeidenheid van die volke van hierdie land kan ekumene laat blom - 'n getuienis van die skriftuurlike uiteensetting van eenheid en verskeidenheid wat één saak en begrip is.

\section{Bibliografie}

Bosch, D. 1997. Transforming mission: Paradigm shifts in theology of mission. Maryknoll: Orbis. 
Boshoff, A. 1999. Waarom moes die Afrikaanse Protestantse Kerk gestig word? Pretoria: Lig en duisternis.

Buitendag, J. \& Van Wyk, T. 2011. Die NHKA op reis na inklusiwiteit 1: Die anatomie van 'n gefragmenteerde/eskatologiese ekklesiologie. HTS Teologiese Studies 67(3). Art. \#1164, 8 pages. http://dx.doi. org/10.4102/hts.v67i3.1164

Dreyer, W.A. 2007. Kan die Kerk nog volkskerk wees? Die Hervormer 100(10):5.

Dreyer, W.A. 2011. Journey from Isolation. HTS Teologiese Studies 67(1), Art. \#869, 9 pages. https://doi.org/10.4102/hts.v67i1.869

Dreyer, Y. 2007. "Volkskerk" of kerk van Christus? Die Hervormer 100(10):6.

Du Plooy, A. le R. 1984. Besinning oor eenheid in kerkverband oor nasionale en taalgrense. I.C.J. Smit, (red.) In gehoorsaamheid. Potchefstroom: PTP. 32-49.

Du Plooy, A. le R. 1986. Kerkreg I. Ongepubliseerde klasdiktaat gebruik by die Teologiese Skool Potchefstroom.

Durant, J. 2008. Is daar 'n weg uit die kerkherenigingskrisis? Die Kerkbode 181(8):9.

Gereformeerde Kerke in Suid-Afrika. 1961. Handelinge van die 34ste Sinodale Vergadering van die Gereformeerde Kerk in Suid-Afrika in sitting byeen te Potchefstroom. Potchefstroom: Admin. Buro, GKSA.

Gereformeerde Kerke in Suid-Afrika. 1964. Handelinge van die 35ste Sinodale Vergadering van die Gereformeerde Kerk in Suid-Afrika in sitting byeen te Potchefstroom. Potchefstroom: Admin. Buro, GKSA.

Gereformeerde Kerke in Suid-Afrika. 1967. Handelinge van die 36ste Sinodale Vergadering van die Gereformeerde Kerk in Suid-Afrika in sitting byeen te Potchefstroom op Woensdag 17 Januarie 1967 en volgende dae. Potchefstroom: Admin. Buro, GKSA. 
Gereformeerde Kerke in Suid-Afrika. 1970. Handelinge van die 36ste Sinodale Vergadering van die Gereformeerde Kerk in Suid-Afrika in sitting byeen te Potchefstroom op Woensdag 17 Januarie 1967 en volgende dae. Potchefstroom: Admin. Buro, GKSA.

Gereformeerde Kerke in Suid-Afrika. 1979. Handelinge van die 40ste sinode te Potchefstroom op 1 O Januarie 1979 en volgende dae. Potchefstroom: Admin. Buro, GKSA.

Gereformeerde Kerke in Suid-Afrika. 2000. Handelinge van die seween-veertigste Nasionale Sinode te Potchefstroom op 10 Januarie 2000 en volgende dae en eerste addendum by die emeritaatsversorgingskombinasie. Potchefstroom: Admin. Buro, GKSA.

Gereformeerde Kerke in Suid-Afrika. 2006. Handelinge van die nege-enveertigste Nasionale Sinode te Potchefstroom op 4 Januarie 2006 en volgende dae en derde addendum by die emeritaatsversorgingstrust. Potchefstroom: Admin. Buro, GKSA.

Gereformeerde Kerke in Suid-Afrika. 2009. Handelinge van die eerste Algemene Sinode te Potchefstroom op 6 Januarie 2009 en volgende dae. Potchefstroom: Admin. Buro, GKSA.

Grove, P. 2004. Konvent bring begrip. Die Kerkbode 173(1):9.

International Conference of Reformed Churches. 2001. Minutes of the fifth meeting of the ICRC from Wednesday 20 June 2001 in Iowa. S.l.: ICRC.

International Conference of Reformed Churches. 2005. Minutes of the sixth meeting of the ICRC from Wednesday 12 October 2005 in Pretoria. S.l.: ICRC.

Kasper, W. 2011. May they all be one. A vision of Christian unity for the next generation. Didaskalia xli(2):13.

Kleynhans, P.J. 1973. Die kerkregtelike ontwikkeling van die Nederduitse Gereformeerde Kerk in Suid-Afrika 1795-1962. D.Th.-proefskrif. Stellenbosch: U.S. 
Kleynhans, H.J. 2009. Kerkbegrip, belydenis en kerkorde in die kerkherenigingsproses van die NG Kerkfamilie in Suid-Afrika. D.Th.proefskrif. Bloemfontein: U.V.

Kriel, H. 2007. Wysiging van ordereëls. Die Hervormer 99(21):2.

Maré, R. 1997. Volkseie kerk. Inougurele rede gehou op 20 Februarie 1991 by die Teologiese Skool van die Afrikaanse Protestantse Kerk. Pretoria: Lig en duisternis.

McGrath, A.E. 1995. Christian theology. An introduction. Oxford: Blackwell.

Nederduitsch Hervormde Kerk van Afrika. 1982. Notule van die 60ste Algemene Kerkvergadering van die Nederduitsch Hervormde Kerk van Afrika in sitting te Pretoria van 29 Oktober 1982. Pretoria: NHKA.

Nederduitse Gereformeerde Kerk (OVS), Nederduitse Gereformeerde Kerk in Afrika; Phororo en die Verenigende Gereformeerde Kerk in SuiderAfrika Saaknommer 536/96.

Nederduitsch Hervormde Kerk van Afrika. 1998. Besluitebundel van die 65ste Algemene Kerkvergadering van die Nederduitsch Hervormde Kerk van Afrika in sitting te Pretoria vanaf 4 Oktober 1998. Pretoria: NHKA.

Nederduitsch Hervormde Kerk van Afrika. 2001a. Agenda van die 66ste Algemene Kerkvergadering van die Nederduitsch Hervormde Kerk van Afrika in sitting te Pretoria vanaf 30 Oktober 2001. Pretoria: NHKA.

Nederduitsch Hervormde Kerk van Afrika. 2001b. Besluitebundel van die 66ste Algemene Kerkvergadering van die Nederduitsch Hervormde Kerk van Afrika in sitting te Pretoria vanaf 30 Oktober 2001. Pretoria: NHKA.

Nederduitsch Hervormde Kerk van Afrika. 2004. Besluitebundel van die 67ste Algemene Kerkvergadering van die Nederduitsch Hervormde Kerk van Afrika in sitting te Pretoria vanaf 26 September 2004. Pretoria: NHKA. 
Nederduitsch Hervormde Kerk van Afrika. 2007a. Besluitebundel van die 68ste Algemene Kerkvergadering van die Nederduitsch Hervormde Kerk van Afrika in sitting te Pretoria vanaf 02 Oktober 2018. Pretoria: NHKA.

Nederduitsch Hervormde Kerk van Afrika. 2007b. Besluitebundel van die 71ste Algemene Kerkvergadering van die Nederduitsch Hervormde Kerk van Afrika in sitting te Pretoria vanaf 23 September 2007. Pretoria: NHKA.

Nederduitse Gereformeerde Kerk. 1857 Acta van die Nederduitse Gereformeerde Kerk.

Nederduitse Gereformeerde Kerk. 1975. Ras, volk en nasie en volkereverhoudinge in die lig van die Skrif. Kaapstad: N.G. Kerkuitgewers.

Nederduitse Gereformeerde Kerk. 1982-1989. Handelinge van die TKK van die drie Afrikaanse susterskerke. Deel Ill. (Ongepubliseerd).

Nederduitse Gereformeerde Kerk. 1990. Handelinge van die agste vergadering van die Algemene Sinode van die Nederduitse Gereformeerde Kerk, gehou in Bloemfontein vanaf 16 Oktober 1990. Bloemfontein: NG Kerk.

Nederduitse Gereformeerde Kerk. 2000. Handelinge van die tiende sitting van die Algemene Sinode van die Nederduitse Gereformeerde Kerk gehou in Bloemfontein vanaf 9 Oktober 2000. Bloemfontein: NG Kerk.

Nederduitse Gereformeerde Kerk. 2000. Notule van die TKK vergadering van die drie Afrikaanse susterskerke gehou op 09 Oktober 2000. (Artikel 7.1.3). (Ongepubliseerd).

Nederduitse Gereformeerde Kerk. 2001. Notule van die TKK vergadering van die drie Afrikaanse susterskerke gehou op 19 Maart 2001. (Art. 7.1.4) ( Ongepubliseerd).

Nederduitse Gereformeerde Kerk. 2002. Handelinge van die elfde sitting van die Algemene Sinode van die Nederduitse Gereformeerde Kerk gehou in Pretoria vanaf 13 Oktober 2002. Bloemfontein: NG Kerk. 
Nederduitse Gereformeerde Kerk. 2004. Handelinge van die twaalfde sitting van die Algemene Sinode van die Nederduitse Gereformeerde Kerk gehou in Hartenbos vanaf 10 Oktober 2004. Bloemfontein: NG Kerk.

Nederduitse Gereformeerde Kerk. 2007. Notule van die TKK vergadering van die drie Afrikaanse susterskerke. (p. 7). (Ongepubliseerd).

Nordholt, H-H, 1970. Apartheid und Reformierte Kirche. NeukirchenerVluyn: Neukirchener Verlag.

Olivier, E. 2011, History of Afrikaans speaking churches in South Africa and the option of ecumenism. Studia Historiae Ecclesiasticae 37(1):3957.

Plaatjies-Van Huffel, M.A. 2017. From conciliar ecumenism to transformative receptive ecumenism. HTS Teologiese Studies 73(3):a4353. https://doi.org/10.4102/hts.v7313.4353

Plaatjies-Van Huffel M.A. 2016. VGKSA reageer op NG Kerk se hertoelating tot WRK. [Intyds]. Beskikbaar: https://kaapkerk.co.za/ vgksa-reageer-op-ng-kerk-se-hertoelating-tot-wrk/

Pont, A.D. 1981. Die historiese agtergronde van ons kerklike reg. Pretoria: Kital.

Pretorius, C. 2007. Waarheid en werklikheid. Die Hervormer 100(10):6.

Reformed Ecumenical Council. 2005. Acts of The Reformed Ecumenical Council in session at Utrecht, The Netherlands from 12 to 26 July 2005 in Utrecht, The Nederlands. Michigan: REC.

Spoelstra, B. 1963. Die Doppers in Suid-Afrika (1760-1899). Kaapstad: Nasionale Boekhandel.

Steenkamp, J.J. 2007. Het ons die evangelie verraai? Die Hervormer 100(6):6.

Timmer, S. 2014. Receptive ecumenism and justification: Roman catholic and reformed doctrine in contemporary context. Dissertations (2009), Paper 362. [Online]. Available: http://epublications.marquette.edu/ dissertations_mu/362 [17 February 2018]. 
Tussenkerklike Kommissie. 1955-1977. Handelinge van die TKK van die drie Afrikaanse susterskerke. Deel I. (Ongepubliseerd).

Tussenkerklike Raad. 1994. Notule van die TKR vergadering van die drie Afrikaanse susterskerke. (p. 7). (Ongepubliseerd).

Tussenkerklike Raad. 2006. Notule van die TKR vergadering van die drie Afrikaanse susterskerke. (p. 12). (Ongepubliseerd).

Van den Berg, A. 1997. Die Belhar-belydenis en die toekoms. Pretoria: Lig en duisternis.

Van der Merwe, R.M. 2009. Die konkretisering van eenheid in 'n plurale en gebroke ekumeniese gemeenskap - 'n gereformeerd-kerkregtelike beskouing. Ph.D.-proefskrif. NWU.

Van der Linde, G.P.L. 1965. Die grondbeginsels van die presbiteriale kerkregeringstelsel. Potchefstroom: Pro Rege.

Van Staden, F.A.H. 1995. Gereformeerd-kerkregtelike probleemareas. Inougurele rede as dosent en hoof van Teologiese Opleiding aan die Teologiese Skool van die Afrikaanse Protestantse Kerk gelewer op 6 Junie 1990. Pretoria: APK.

Van Wyk, D.J.C. (Jnr). 2003. Kommentaar. Die Hervormer $96(10$ ):4.

Van Wyk, D.J.C. (Jnr). 2004. Kommentaar. Die Hervormer 97(03).

Van Wyk, G.M.J. 2004. Ekumenisiteit. Die Hervormer 97(09):4.

Van Wyk. D.J.C. (Jnr). 2007. Ekumene en kerkeenheid. Die Hervormer 100(12):1.

Van Wyk, J.H. 2007a. Is Christus verdeel? Teologies nagedink oor die regverdiging van 'n kerkskeuring. Lesing gehou gedurende die Gereformeerde Teologiese Vereniging se byeenkoms te Potchefstroom, September 2007. (Ongepubliseerd.)

Van Wyk. J.H. 2007b. Die redakteur gesels met prof. Natie van Wyk. Die Kerkblad 110(3202):9. 
Veenhof, J. 1992. Geschiedenis van theologie en spiritualiteit in de gereformeerde kerken. In M.E. Brinkman (red). 100 jaar theologie. Aspekten van een eeuw theologie in de Gereformeerde Kerken in Nederland (1892-1992) (Kampen: Kok). 14-95.

Vorster, J.D. 1956. Die Kerkregtelike Ontwikkeling van die Kaapse Kerk onder die Kompanje 1652-1795. Potchefstroom: Pro Rege. 